\title{
A STUDY OF THE BLOOD CHOLESTEROL IN CHILDHOOD*
}

BI

\author{
KATHLEEN M. WARD, M.D., L.R.C.P., M.R.C.S. \\ (From the laboratory of the Royal Lirerpool Children's Hospital.)
}

\section{THE BLOOD-CHOLESTEROL LEVEL IN HEALTHY CHILDREN.}

Previous investigations.-From a perusal of the literature it appears that the subject of the blood-cholesterol lerel in healthy children has not been attacked svistematically hitherto. Much work has been done on the normal percentage of cholesterol in both the whole blood and the plasma of adults, though many differing methods have been employed. More estimations hare been made on the blood of babjes under two than on older children, but the effects of age and sex hare not been studied in any detail. Some division into age groups has been attempted, but a variety of methods of estimation has been adopted and rather variable results obtained, so that before beginning any work on morbid children, it was essential to have a table of normal ralues, obtained by the same method as that used in the other work.

Normal percentage Ix adclts.-Taking a reriew of the literature the normal adult value, as given by different workers, is fairly uniform.

Bloor $^{1}$ who quotes the arerage of figures giren in the litera ture as being $170 \mathrm{mgrm}$. per cent , gires results which are slightly higher. His own values are $210-240 \mathrm{mgrm}$. per cent. for women and 190-250 for men. Denis ${ }^{2}$ has somewhat similar values : 16j-225 for women and 192-255 for men. Chauffard, Laroche and Grigaut give the normal as 150-180, and MacAdam and Shiskin $^{3}$ are in close agreement with results of $133-191$, the average being $161 \mathrm{mgrm}$. per cent. Wades also considers the normal value to be 165 . Hunt's $\mathrm{s}^{5}$ figures are slightly higher (17t mgrm. per cent.).

Normal Percestage is childrex.-The normal percentages for children quoted in the literature show a very much wider variation. Some of these figures apply to whole blood and others to plasma, which may in part account for some of the discrepancies.

Gordon and Cohn ${ }^{6}$, using Bloor's method on serum, give the arerage for cord blood as 89 ; in the first week of life as 87 ; and afterwards up to two rears as 110-190 mgrm. per cent.

Manicatide, Bratesco and Rusesco ${ }^{7}$ using Grigaut's method on serum give an arerage of 131 under four months, and 116 from four months to one year. Their average they took as 125 mgrm. per cent. for all babies whether artificially or breast fed.

Baylac and Sendrail ${ }^{8}$ using Grigaut's method on serum give 149 as the arerage, which is in agreement with Baranski's results of $150 \mathrm{mgrm}$. per cent. Simone ${ }^{10}$ gives values of $67-105$, and Varone's ${ }^{11}$ results are also rather lower than the arerage, giving 115 as normal for infants

* Part of a thesis accepted for the M.D. degree, Lirerpool Lniversity. 
under one year, and 137 as the arerage for children of 2 to 8 years. Dorlencourt and Seitzoff ${ }^{2}$ give a higher normal of 140 . The results of Gladys Boyd ${ }^{13}$ are highest of all. Using Bloor's method she gives a figure of $185 \mathrm{mgrm}$. per cent.

Method of estimation.-Many methods for the estimation of the cholesterol in the blood have been adrocated. Probably the most accurate is the digitonin method, but this is difficult of operation and very expensive. The colorimetric methods employed give slightly higher results than the grarimetric, but on the whole they are accurate. In the present investigation, large numbers of estimations had to be performed and a reasonably rapid method was accordingly essential ; and as the patients were children, a simple method of obtaining the required small quantity of blood was necessary. The method described by Leiboff ${ }^{14}$ appeared to fulfil these stipulations the most conveniently. A small amount of blood only is needed, the apparatus is comparatively simple, and there is very little opportunity for experimental error to occur. The results appear very consistent and thus justify the adoption of this method.

As a preliminary precaution, estimations were made on the writer's own blood, using first a modified Myers-Wardell ${ }^{15}$ method and comparing the results obtained by Leiboff's method. The results agreed very well as can be seen in the following list :-

Myers-Wardell method
Leiboft's method ",
,
",
,$"$
,

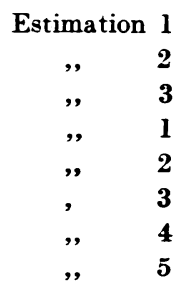

$\begin{array}{llc}156 & \text { mgrm. } & \text { per cent. } \\ 156 & , & , \\ 156 & , & , \\ 153 & , & " \\ 155 & , & , \\ 169 & , & , \\ 155 & , & , \\ 160 & , & ,\end{array}$

Leiboff's method.-This method is briefly as follows :-

The patient's finger is cleaned thoroughly with ether and pricked. $\quad \cdot 5 \mathrm{c} . \mathrm{cm}$. of blood can be obtained easily in this manner. $\cdot 2 \mathrm{c.cm}$. of this blood is measured out and run on to a specially prepared filter paper thimble end, which is then allowed to dry at room temperature. 5 c.cm. of pure anhydrous chloroform is poured into the extractor tube and the filter paper disc is dropped into position. The tube is attached to a reflux condenser, immersed in a beaker of water, and extraction allowed to proceed for twenty-five minutes. At the end of this time, the extractor tube is remored from the condenser and cooled. The disc is taken out and discarded. Chloroform is now added exactly to the $\mathbf{5} \mathrm{c.cm}$. mark. In a corresponding extractor tube is poured $\mathbf{5} \mathrm{c.cm}$. of a standard solution of cholesterin in chloroform, containing $\cdot 3 \mathrm{mgrm}$. cholesterin per 5 c.cm. To both tubes are added $2 \mathrm{c.cm}$. acetic anhydride and $\cdot 2 \mathrm{c.cm}$. concentrated sulphuric acid. After mixing and cooling, the tubes are placed in a dark cupboard for twenty minutes. By this time the colour has dereloped and the contents of the tubes are poured into the cups of a Bausch-Lomb colorimeter and the estimations are made.

Cases investigated.-The children chosen to represent the normal, were sound healthy children from an orphanage in the vicinity. They were all leading a normal life of a more or less standardized type, having similar amounts of exercise, diet and school work.

Fifty-nine cases in all were studied, including twenty-six boys and thirtythree girls. All the children were between the ages of thirteen and six years. 
TABLE 1.

The Cholestreol heVEL is 59 yormal childrex.

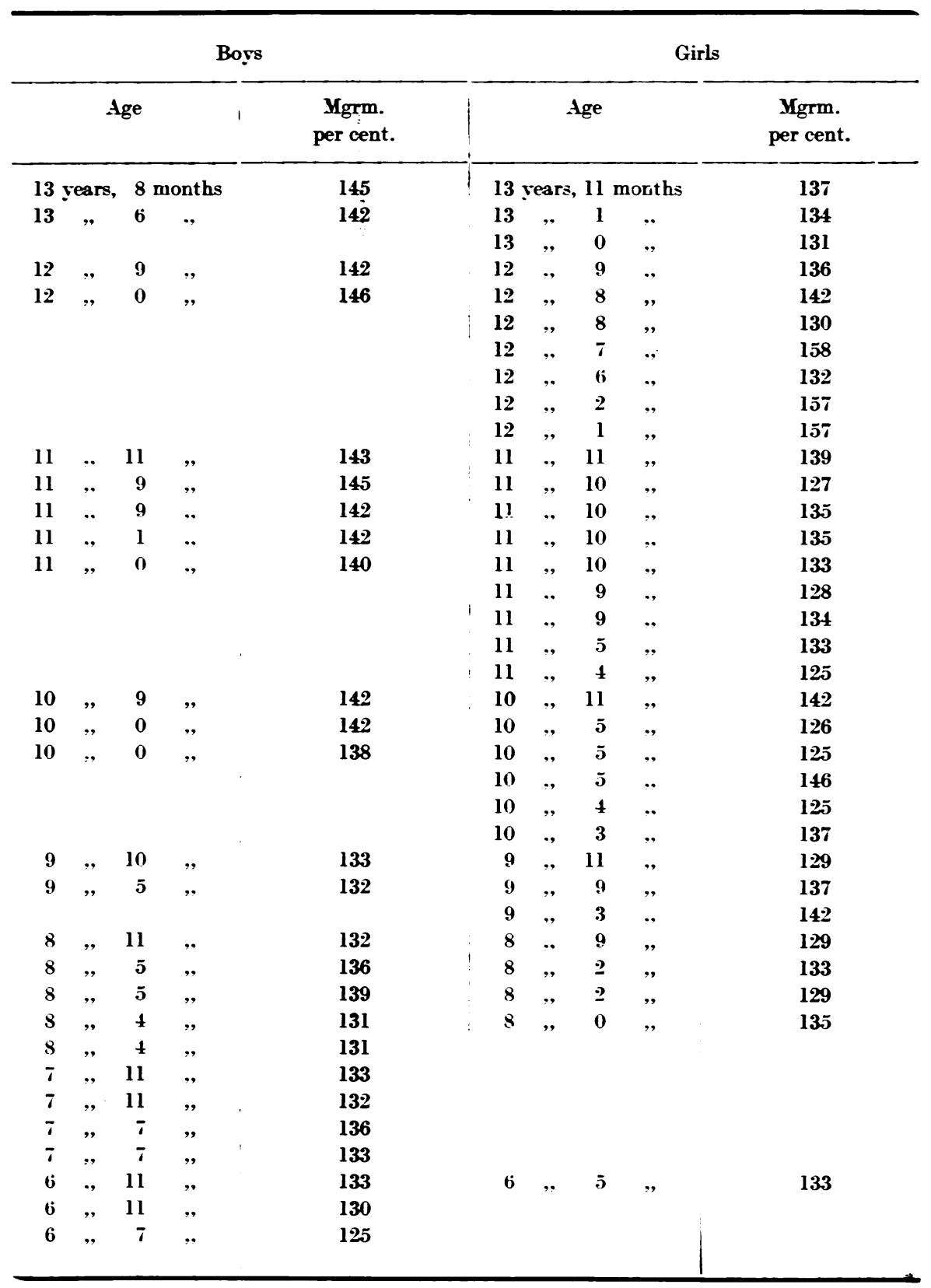


Chart I.

THE BLOOD CHOLESTEROL OF NORMAL CHILDREN.

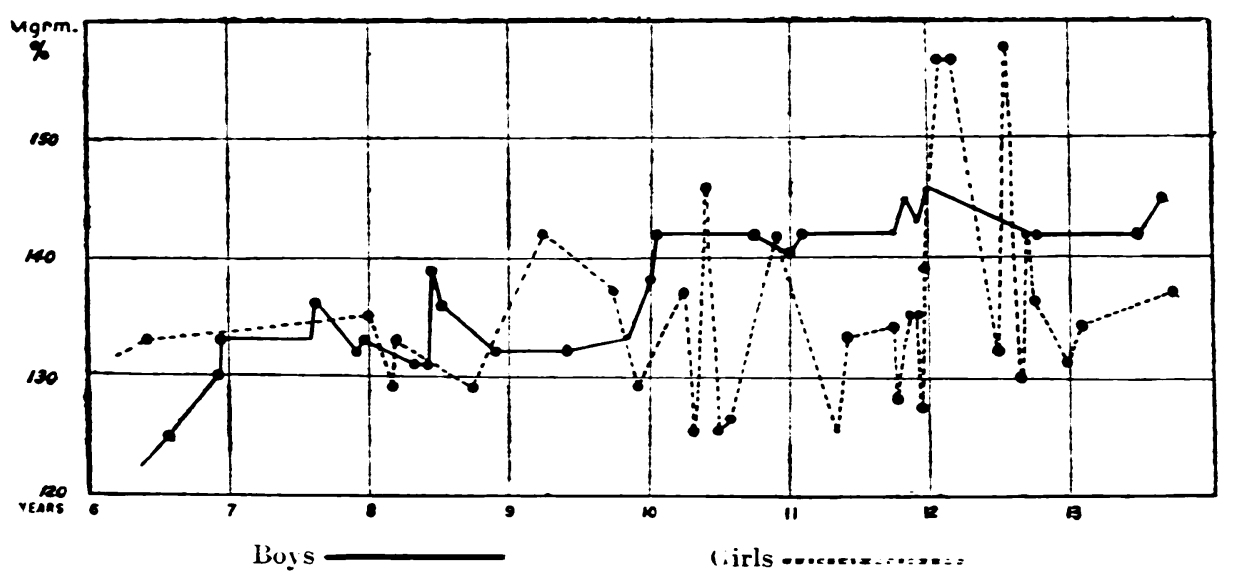

TABLE 2.

ATERAGe bLOOD CHOLESTEROL FOR EACH AGE GROTP.

\begin{tabular}{cccc}
\hline & Bors & & \multicolumn{2}{c}{ Girls } \\
\cline { 2 - 4 } $\begin{array}{c}\text { Age } \\
\text { in rears }\end{array}$ & $\begin{array}{c}\text { Mgrm. } \\
\text { per cent. }\end{array}$ & $\begin{array}{c}\text { Age } \\
\text { in sears }\end{array}$ & $\begin{array}{c}\text { Mgrm. } \\
\text { per cent. }\end{array}$ \\
\hline 13 & 144 & 13 & 134 \\
12 & 144 & 12 & 145 \\
11 & 142 & 11 & 132 \\
10 & 140 & 10 & 133 \\
9 & 132 & 9 & 136 \\
8 & 134 & 8 & 131 \\
7 & 134 & 7 & - \\
6 & 129 & 6 & 133 \\
& & & \\
\hline
\end{tabular}

\section{Cinart II.}

THE RANGe OF VAPIATION AT EACH AliE.

( max. per cent. cholesterol minus min. per cent. cholesterol).

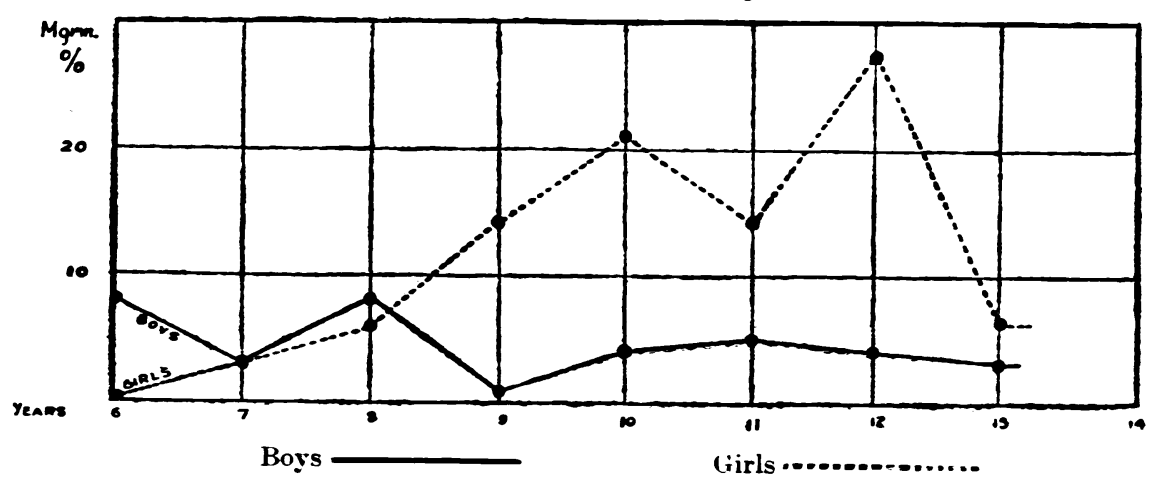


Results.-Table 1 and Chart 1 show the results obtained in each case graduated according to age.

Table 2 shows the arerage readings of the blood cholesterol for each age group.

Discussion.-Table 1 and 2 show the results obtained and for greater ease of explanation these have been expressed in the form of graphs also (Charts I and II). From a consideration of the figures giren, some facts of importance emerge.

First, it is obvious that a consistent level of blood cholesterol is maintained throughout childhood. In the case of boys, this shows a steady and progressive rise towards puberty, with a rather more rapid increase from the age of nine onwards. From nine to ten years the curve is steep, but a more even level is maintained from ten to thirteen. In the case of girls the amount of variation at every age is markedly greater than that shown by the boys, and this is especially manifest between the ages of ten and thirteen when a definite degree of instability exists, the curve tending to show a drop at eleven with a subsequent rise at twelve. The whole curve is entirely different from that of the boys, a progressive rise from the time of the second dentition until puberty not being apparent.

A curve of the range of variability has been plotted (Chart II), and this shows very clearly the wide range of variation which occurs in girls, especially at the ages of ten, eleren and twelre. This may be regarded as being coincident with the onset of puberty.

It will be seen also from a consideration of the graphs that the cholesterol level in girls tends on the arerage to be somewhat lower than in boys at erery age.

\section{THE BLOOD-CHOLESTEROL LEVEL IN CHILDHOOD DURING DISEASE.}

From a consideration of the literature, it is apparent that the blood cholesterol level is disturbed during the course of many diseases.

During the present investigation, many examples of rarious diseases hare been studied, but chief among these have been patients showing various phases of rheumatic infection. The main object in view being to determine whether cr not there is any abnormality in the chclesterol content of the blood during the course of jurenile rheumatism, estimations have been made in cases selected from all stages of the disease. It was hoped that this would show some facts of interest. In addition, an attempt was made to correlate the results with obvious foci of sepsis in teeth and tonsils, and also to compare them with a similar series of cases in which leucocyte counts were performed. 
TABLE 3.

GrotP A. THE CHOLESTEROL LEVEL IN CHILDREx SCFFERIYG FROM ACVTE RHECMATISM.

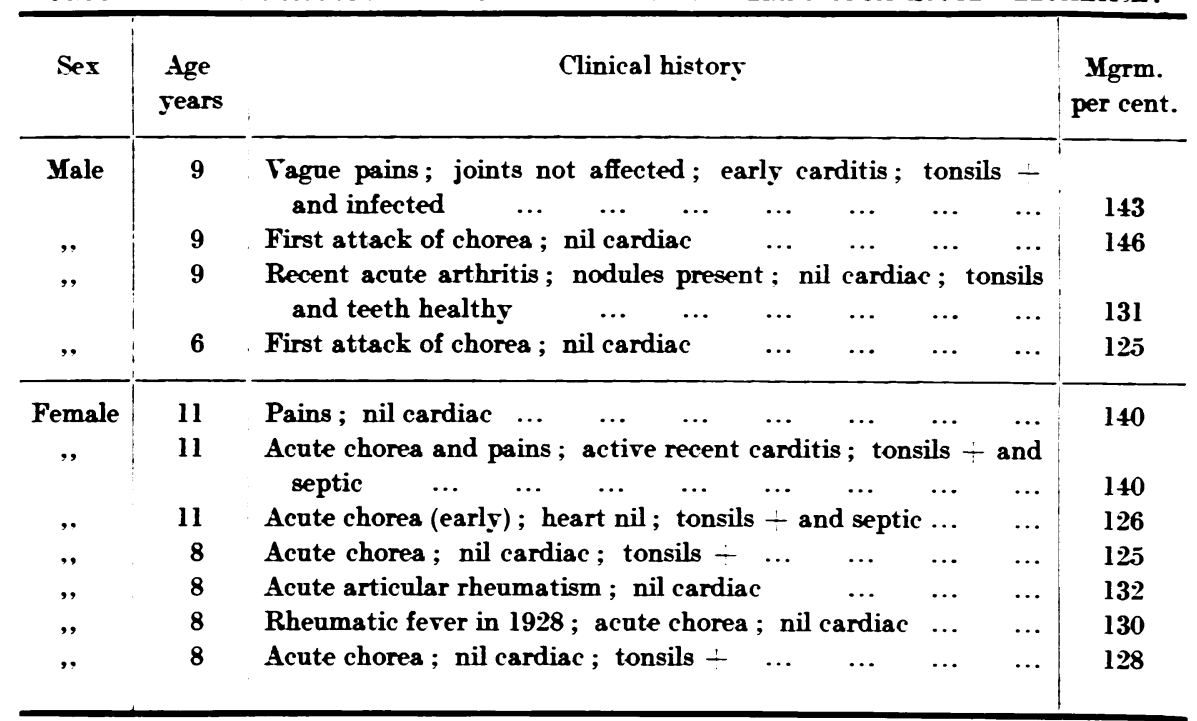

TABLE 4.

GroUP B. THE CHOLESTEROL LEVEL IX CHLDREX STFTERING FROY ChROXIC RHECXATISY.

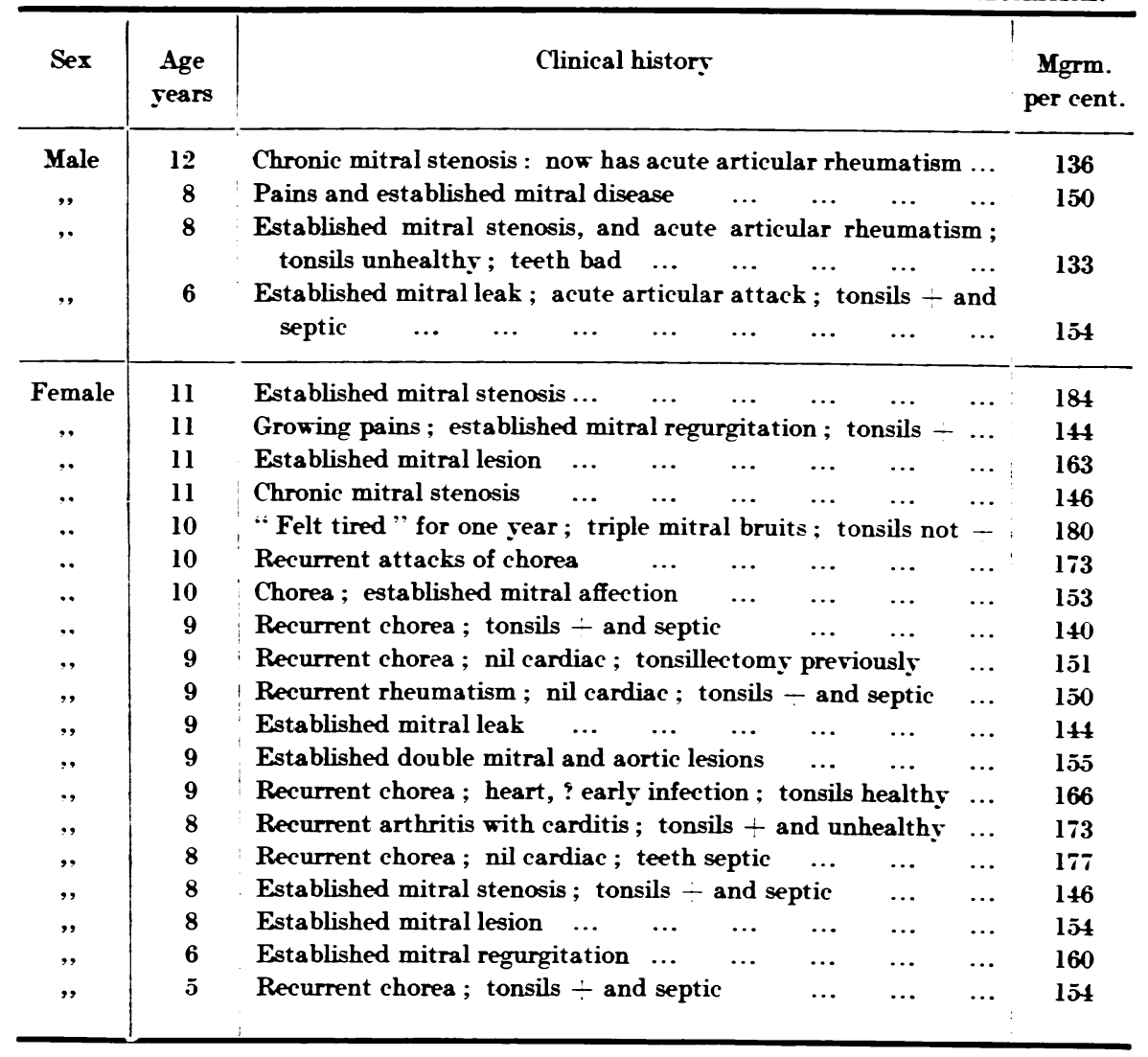


Chart III.

THE BLOOD CHOIESTEROL IN ACUTE AND CHRONIC RHECMATISM.

(Arerage for each age group).

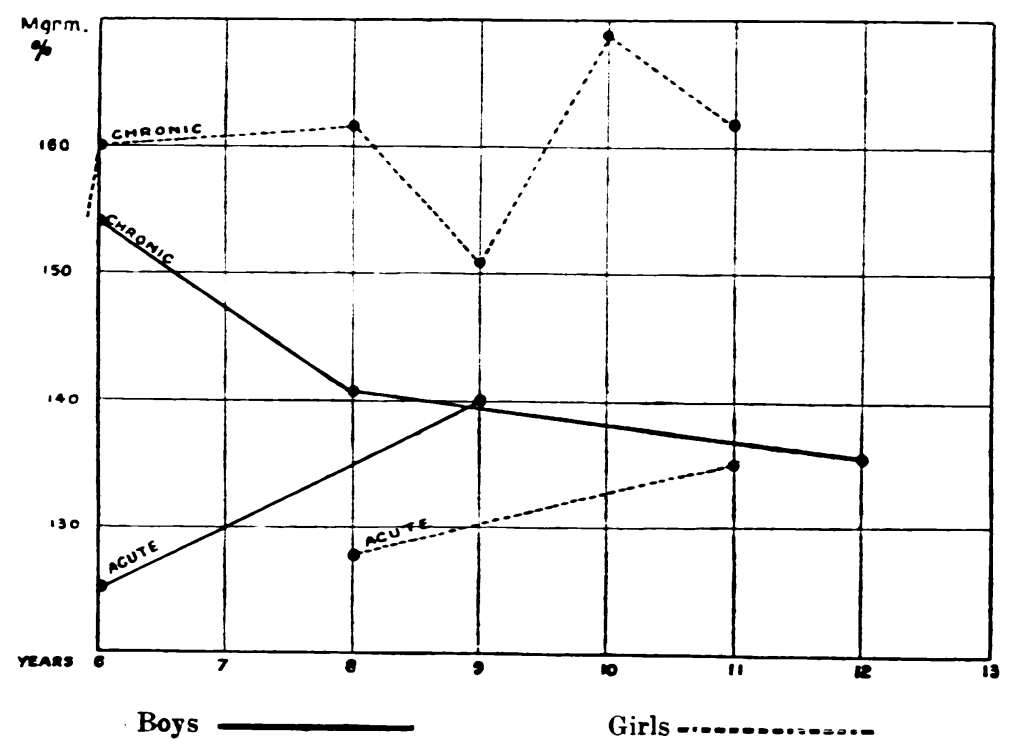

TABLE 5.

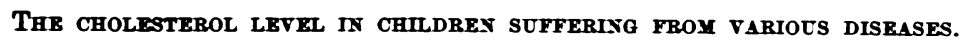

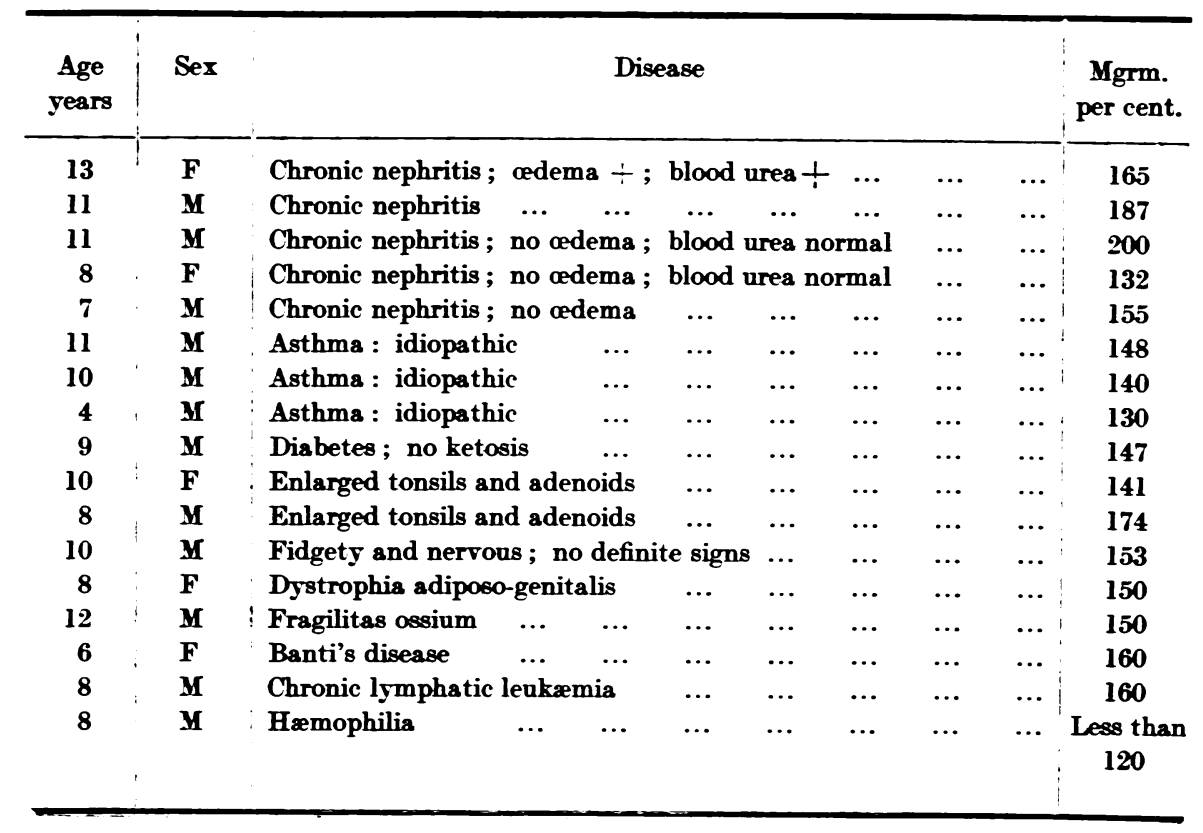


This part of the inrestigation has been carried out on cases of jurenile rheumatism, but as this term embraces such a number of widely differing sets of symptomatology and consequently varied clinical pictures a little classification was necessary. The best dirision from the point of riew of this paper seems to be into two large groups :-

GrocP A.-Recent, acute, active rheumatism including muscular pains, swollen joints, pancarditis and chorea, usually associated with some degree of fever (Table 4).

GrocP B.-Rheumatism of a more chronic type, including recurrent chorea, myocarditis, endocarditis and established valrular lesions. Some of these cases were undergoing a secondary acute relapse and the picture becomes more complicated, but for the sake of clarity and ease of explanation, a short clinical history is appended to each case (Table $\tilde{5}$ ).

In addition to the cases of rheumatic infection, some other diseases have been studied (Table 6). These form a heterogeneous group, including cases of chronic nephritis, idiopathic asthma, chronic lymphatic leukæmia, fragilitas ossium and a few patients with chronic infected tonsils and adenoids. The cases of chronic nephritis were thought to be of interest in view of the increase in blood cholesterol reported in this condition; and the asthma cases represented specimens of an allergic condition. The cases with septic tonsils were chosen for comparison with cases of rheumatic infection in which similarly infected throats were present.

\section{DISCCSSION OF RESLLTS.}

From a consideration of the known facts of the physiology and pathology of cholesterol in the animal body, it is apparent that a great amount of knowledge is not arailable upon these points. Conjecture is rife, but solidly established facts are relatively few, and even those known are difficult of correlation into a complete picture and many gaps are left unfilled. As this is the case, to draw sweeping conclusions from the results quoted would be unjustifiable and almost sertainly fallacious. Some facts and points of interest do emerge, howerer, and these will now be considered.

For a full appreciation of these facts, a few obserrations on the physiology of the child are necessary. That the metabolism of the normal healthy child differs in many essential ways from that of the healthy adult is undoubted. On the whole, the balance of the child's biochemistry is rery much more easily influenced by external factors and consequently is much more readily disturbed. The fact that growth is taking place rapidly means that the whole metabolism is in a constantly changing state, anabolism being much more marked than katabclism, although this is taking place to a less degree, and no organ of 
the body remains static for any length of time. A review of the growth process is giren in Abt's Pediatrics ${ }^{16}$. The termination of the infantile and the beginning of the jurenile growth cycle at about the time of weaning is characterized by profound metabolic changes, the infant's body haring to adjust itself to an altered diet and consequently to a change of materials for building up new tissues. Again, at the junction of the jurenile and adolescent growth cycles, there is a similar metabolic uphearal, and a relatire instability of the growth process is shown. In the investigation quoted by Abt the increase of weight and stature, and the rariability of each, in a number of healthy boys and girls was obtained. The boys showed a steady yearly increment of weight and height, while the girls gare a far less steady increment. The rariability of weight of the boys, which was not great at any age, was slightly increased at the age of eight and nine years. The girls, showing at all

Cinart IV.

THE VARIABILITY OF HEIGHT AND WEIGHT. (from Abt's Pediatrics).

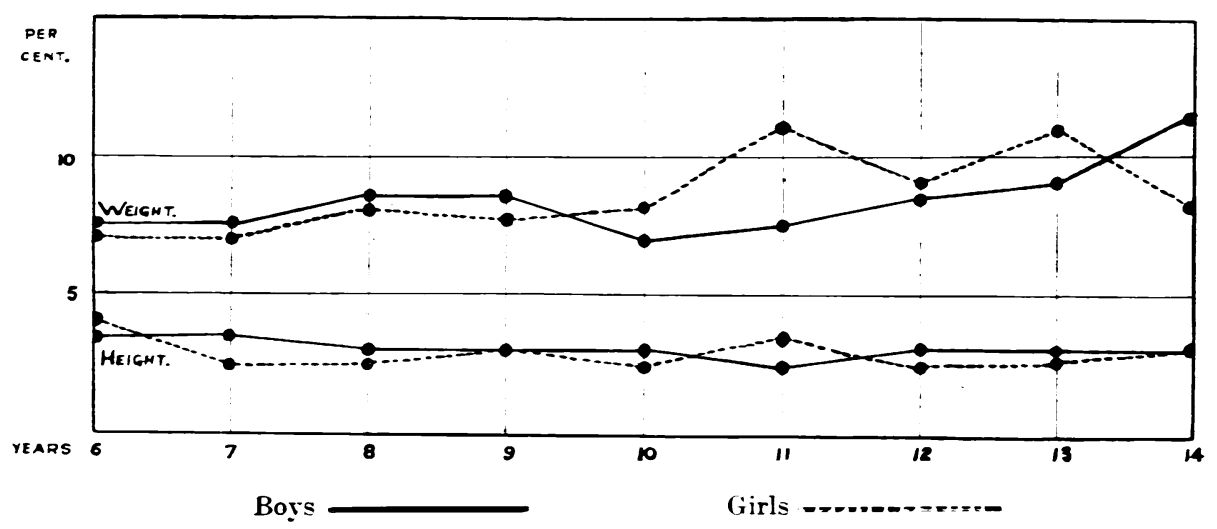

ages a more marked variability, accentuated this slightly at the age of eight, but much more sc at ten, eleren, twelve and thirteen years. The variability of height was not quite so obrious, and did not appear to affect any one age group more than another. It becomes apparent at once, that the two sexes show a marked difference in their response to the grewth process (Chart IV).

Passing on from a consideration of the effect of growth, the basal metabolism may next be discussed. The basal metabolism appears to increase with age during babyhood, reach its maximum at the age of four years, and then fall gradually, reaching the normal adult ralue at about twenty years. It is a well recognized fact that a relatively high basal metabolism characterizes the period of growth. In this as in the growth process, the influence of sex is marked from early years, it being definitely lower in the female than in the male. Sonden and Tigerstedt (quoted by Abt) found that under like conditions in the young, the carbon dioxide output both per kilogramme of body weight and per square metre of surface, is considerably greater in males than in females. 
This difference becomes less apparent with increasing age, until in old age it disappears completely. Benedict and Talbot also state that boys have a higher arerage metabolism than girls of the same weight.

A consideration of the differences between the blood of the adult and that of the child is illuminating also. At birth the specific grarity of the baby's blood is equal to that of the adult, but thereafter it rapidly becomes less and remains at a lower level, the boys at all ages showing a higher specific gravity than the girls. Feldman ${ }^{17}$ considers that the specific gravity is not dependent on the number of corpuscles, but on their hæmoglobin content, and this is low in childhood, rising gradually to the adult level at about puberty.

A further point of difference is the relative numbers of the cells of the blood. These are all greater in the child than in the adult, the red cells averaging 5,800,000 from 1-14 years, and the white cells 10,000-7,000 per c.mm.; also there is a relative lymphocytosis of $30-50$ per cent. of all white cells, owing to a greatly increased activity of adenoid tissue in children in which the tonsils, thymus, lymphatic glends and spleen all take part.

As regards the chemical constituents of the blood, the non-protein nitrogen content, comprising urea, uric acid and creatinine are within the same limits as in the adult, but creatine behares rather differently in the child. Feigl ${ }^{18}$ belieres that there is a tendency rerealed by the arerages of his different age groups for the creatine and creatinine of the blood to increase with age from childhood onwards. Fonteyne and Inglebrecht ${ }^{19}$, however, did not discover any relation of age to creatinine, but agreed that it influenced the amount of creatine. Rose 20 showed that children of both sexes excrete creatine in relatively large quantities, and regard creatinuria as a normal accompaniment of the growth process. Rose thought this persisted in both sexes until or even after puberty, but Krause ${ }^{21}$ believes that boys cease to excrete creatine at the age of five or six years, while girls usually, but not necessarily always, continue to excrete it for some years longer. He believes that the excretion of creatine is entirely dependent on the balance maintained between its formation and destruction, and that the power of dealing with it is less well developed in the child than in the adult.

From the time of birth onwards the food of the child, consisting as it does mainly of carbohydrates, proteins, fats and salts, is comparable to that of the adult, but the use to which these substances are put differs somewhat. In the adult, protein is broken down and used to repair damage to vital cells, while fats and carbohydrates supply the necessary fuel. It has been shown also, by Cathcart, that carbohydrates are necessary for synthetic processes in the cells in connection with protein metabolism and do not act merely as sparers of protein. In the child, however, anabolism is proceeding rapidly and a source of supply of energy which is easy of obtaining must be at hand. Substance metabolism is usually taken to mean chiefly the metabolism of proteins, since these constitute the essential substrata of living protoplasm. Salts rank next in importance, but fats and carbohydrates are regarded as being merely accessory. Abt considers it doubtful if the attitude of regarding the 
fats and carbohydrates merely as fuel is correct. Lipoid matter, which is present in company with the fats, is of great importance structurally, especially in the building up of the nerrous system.

From this brief summary of some of the points of difference between the metabolism of child and adult it is seen that the numerous factors taking part in the growth process seem to be responsible and that these appear to behare rather differently in the case of the boys than in that of the girls.

Some curves are reproduced (Chart 4) from Abt's work on pædiatrics showing the variability of growth and height at different ages in boys and girls and from these it is seen at a glance that the variation in height is not marked at any age in either sex, but that there is an increased variability in the weight curve, which is much more evident in the case of the girls. It is interesting to compare this curve with that already given as indicating the variability of blood cholesterol at different ages.

In both of the latter curres the rariations are rather more accentuated than in the case of the growth curves, but here again the girls show a wider range, and in each case this appears to show more at a year earlier than in the growth curve. For example, the two peaks of the growth rariation are at eleven and thirteen years, while those of cholesterol variation are at ten and twelve years. It seems not unlikely that there may be a relationship between the two, and that this is not merely accidental, cholesterol possibly playing some important part in the process of growth. Further confirmation of this riew is found in the work of Shope ${ }^{22}$ in America. He states that a number of investigators have surmised that differences in blood-cholesterol level occur in organisms of various ages and differing stages of development. Roffo ${ }^{23}$ experimenting on rats found that the blood cholesterol increased between three and fire months of age, Baker and Carrel ${ }^{24}$ using chickens found a marked difference with age. Shope used for his investigations cattle, rabbits and guinea pigs all of varying ages. He found the variations with age to be of two types :(a) a marked and rapid increase from birth, lasting throughout the early life of the animal ; and (b) a less marked but more gradual decline with adrancing age. In all cases he found the changes in cholesterol content of the blood to be more uniform and regular in male than in female animals. In female guinea pigs, the blood cholesterol showed many irregular fluctuations which in many cases were unrelated to age, and Shope questions whether possibly cholesterol serves more functions in the female organism than in the male. These fluctuations are, in the case of female children fully confirmed in the present inrestigation, but their exact interpretation is not possible at the present stage of our knowledge of the functions of cholesterol in the body.

Passing on from the normal figures giren, it is necessary to say a few words about the rheumatism curres, and the figures obtained from cases of other diseases. Here again, the results are not easy of interpretation. From Table 3 (Group A) it may be concluded that during the more acute phases of rheumatism, the blood cholesterol is not greatly disturbed. In the first two cases in Table 3 the figures are perhaps slightly higher than normal, but on the arerage the figures are within normal limits and do not show much rariation. 
Turning to the results in the chronic rheumatism group (Table 4) very different figures are found. The general trend is for an arerage higher than the normal for any age, in many cases this being rery marked. Cases having an acute attack superimposed on a chronic cardiac lesion show a lower cholesterol level than those with uncomplicated heart disease. No direct association with infected teeth or tonsils could be traced, some cases with chronic sepsis showing an increase in cholesterol and others none, but in this connection it is interesting to note that a case of chronically infected tonsils, without any rheumatic șmptoms did give a very high result.

Kipp ${ }^{25}$ during his studies of pneumonia traced a relationship between the number of leucocytes in the blood and its cholesterol content, and in the present investigation many leucocyte counts were performed, but no parallelism could be made out. The arerage counts in both the acute and chronic cases of rheumatism were between the limits of 6,000 and 12,000 cells per c.mm. in a few cases rising to 15,000 per c.mm., but as has been stated already the normal may be regarded as lying between 7,000 and 10,000 per c.mm. so that these counts show a very mild grade of leucocytosis, and this did not appear to bear any relationship to the increased cholesterol in the more chronic cases. The hæmoglobin content of the blood also has been thought to have an influence on the cholesterol content, but here again explanations break down, as many of these children have a marked secondary anæmia.

The most reasonable explanation which can be put forward at the present time with the amount of knowledge at our disposal is that of the growth process again. It is a well known fact that during the course of chronic jurenile rheumatism growth is much impeded, the children being thinner than normal and often under the arerage in size, and it may be suggested that possibly the excess of cholesterol in the blood would in the normal course play some part in anabolism, but that the disorganization of the growth process by the rheumatic condition leads to a slight degree of accumulation in the blood.

There is less interest attached to a consideration of Table 6 which comprises a group of cases suffering from fairly common diseases. Included in this series are five cases of chronic nephritis, one of which showed marked œdema. In four out of the five cases a greatly increased blood cholesterol was found, one case giving as much as $\mathbf{2 0 0} \mathbf{m g r m}$. per cent., which was the highest reading recorded in the whole investigation. Three cases of idiopathic asthma, one of diabetes without ketosis, and one of chronically infected tonsils and adenoids, vielded normal results. Two cases of dystrophia adiposo-genitalis gare results rather higher than normal, as did a case of Banti's disease and one of chronic lymphatic leukæmia. A single case of hæmophilia gare a result which was too weak to estimate with the usual standard solution used in the colorimeter, and was therefore less than $120 \mathrm{mgrm}$. per cent. The child, aged eight, was having a fairly severe hæmorrhage at the time the investigation was made.

No explanation of these results is attempted at the present time, but they are recorded, being of interest in that they confirm the results already published in the literature. 


\section{General conclusions.}

Estimations of the blood cholesterol of children of both sexes between the ages of six and thirteen lead to the following conclusions :-

1. The arerage percentage of blood cholesterol in healthy boys increases as the age increases and the percentage in indiridual bors does not differ greatly from the average for that age.

2. The arerage blood cholesterol of healthy girls increases much less with age than that of healthy boys, and the percentage of cholesterol in individual cases often departs widely from the arerage for that age.

3. In acute jurenile rheumatism the arerage percentage of cholesterol in the blood is normal, but in chronic rheumatism it shows a definite tendency to be greater than normal. It is suggested tentatively that this abnormally high level is related to the disordered growth which frequently attends chronic jurenile rheumatism.

4. Daring the course of the parenchymatous type of chronic nephritis in children, the blood cholesterol rises, as in adults.

5. The blood cholesterol is normal in idiopathic asthma and in diabetes which is being controlled by insulin.

In conclusion, I wish to express my thanks to Dr. Dingwall Fordyce and to Professor Ramsden for much valuable criticism and advice.

\section{REFERENCES.}

1. Bloor, W. R., J. Biol. Chem., Baltimore, 1916, XXV, 577.

2. Denis, W., Ibid., 1917, XXIX, 93.

3. Macadam, W., \& Shiskin, C., Quart. J. Med., Oxford, 19-2-1923, XVI, 193.

4. Wade, P. A., Am. J. Med. Sc., Philadelphia, 1929, CLXXVII, 790.

5. Hunt, H. M., New England J. Med., Boston, 1929, CCI, 659.

6. Gordon, M. B., \& Cohn, D. J., Am. J. Dis. Child., Chicago, 1928, XXXVI, 192.

7. Manicatide, M., Bratesco, A., \& Rusesco, A., Compt. rend. Soc. de biol., Paris, 1927, XCVI, 1240.

8. Baylac, J., \& Sendrail, M., Bull. et mem. Soc. méd. d. hôp. de Paris, Paris, 1928, LII, 33.

9. Baranski, quoted by Baylac \& Sendrail, tide supra.

10. Simone, quoted by Baylac \& Sendrail, ride supra.

11. Varone, L., Rir. di Clin. pédiat., 1929, XXVII, 599.

12. Dorlencourt, H., \& Seisoff, C., Bull. Soc. de pédiat. de Paris, Paris, 1929, XXVII, 352

13. Boyd, G., Am. J. Dis. Child., Chicago, 1929, XXXVIII, 490.

14. Leiboff, S. L., J. Biol. Chem., Baltimore, 1924, LXI, 177. 
15. Yyers, V. C., \& Wardell, E. L., Ibid., 1918, XXXVI, 147.

16. Abt's Pediatrics, 1924, I.

17. Feldman, W. M., Antenatal \& Pastnatal Child Physiology, London, 1920

18. Feigl, J., Arch. f. Exp. Path. u. Pharmak., Leipsic, 1918, LXXXIII, 335

19. Fonteyne, P., \& Inglebricht, P., Ann. de med., Paris, 1923, XIV, 470.

20. Rose, W. C., J. Biol. Chem., Baltimore, 1911-1912, X, 26.5.

21. Krause, quoted in Hunter's Creatine \& Creatinine.

22. Shope, R. E., J. Biol. Chem., Baltimore, 1928, LXXX, 141.

23. Roffo, A. H., Compt. rend. Acad. d. sc., Paris, 1925, CLXXX, 1529.

24. Baker, L. E., \& Carrel, A., J. Exp. Med., N.Y., 1927, XLV, 305.

25. Kipp, H. A., J. Biol. Chem., Baltimore, 1920, XIIII, 413. 